\title{
Observations of peroxyacetyl nitrate (PAN) in the upper troposphere by the Atmospheric Chemistry Experiment- Fourier Transform Spectrometer (ACE-FTS)
}

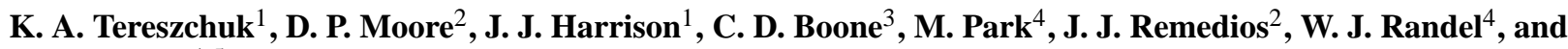 \\ P. F. Bernath ${ }^{1,5}$ \\ ${ }^{1}$ Department of Chemistry, University of York, Heslington, York, UK \\ ${ }^{2}$ National Centre for Earth Observation (NCEO), Department of Physics \& Astronomy, \\ University of Leicester, Leicester, UK \\ ${ }^{3}$ Department of Chemistry, University of Waterloo, Waterloo, Ontario, Canada \\ ${ }^{4}$ National Center for Atmospheric Research (NCAR), Boulder, Colorado, USA \\ ${ }^{5}$ Department of Chemistry \& Biochemistry, Old Dominion University, Norfolk, Virginia, USA \\ Correspondence to: K. A. Tereszchuk (keith.tereszchuk@york.ac.uk)
}

Received: 20 December 2012 - Published in Atmos. Chem. Phys. Discuss.: 15 January 2013

Revised: 25 April 2013 - Accepted: 12 May 2013 - Published: 6 June 2013

\begin{abstract}
Peroxyacetyl nitrate $\left(\mathrm{CH}_{3} \mathrm{CO} \cdot \mathrm{O}_{2} \mathrm{NO}_{2}\right.$, abbreviated as PAN) is a trace molecular species present in the troposphere and lower stratosphere due primarily to pollution from fuel combustion and the pyrogenic outflows from biomass burning. In the lower troposphere, PAN has a relatively short lifetime and is principally destroyed within a few hours through thermolysis, but it can act as a reservoir and carrier of $\mathrm{NO}_{\mathrm{x}}$ in the colder temperatures of the upper troposphere, where UV photolysis becomes the dominant loss mechanism. Pyroconvective updrafts from large biomass burning events can inject PAN into the upper troposphere and lower stratosphere (UTLS), providing a means for the long-range transport of $\mathrm{NO}_{\mathrm{x}}$. Given the extended lifetimes at these higher altitudes, PAN is readily detectable via satellite remote sensing.

A new PAN data product is now available for the Atmospheric Chemistry Experiment Fourier Transform Spectrometer (ACE-FTS) version 3.0 data set. We report observations of PAN in boreal biomass burning plumes recorded during the BORTAS (quantifying the impact of BOReal forest fires on Tropospheric oxidants over the Atlantic using Aircraft and Satellites) campaign (12 July to 3 August 2011). The retrieval method employed by incorporating laboratoryrecorded absorption cross sections into version 3.0 of the ACE-FTS forward model and retrieval software is described
\end{abstract}

in full detail. The estimated detection limit for ACE-FTS PAN is 5 pptv, and the total systematic error contribution to the ACE-FTS PAN retrieval is $\sim 16 \%$.

The retrieved volume mixing ratio (VMR) profiles are compared to coincident measurements made by the Michelson Interferometer for Passive Atmospheric Sounding (MIPAS) instrument on the European Space Agency (ESA) Environmental Satellite (ENVISAT). The MIPAS measurements demonstrated good agreement with the ACE-FTS VMR profiles for PAN, where the measured VMR values are well within the associated measurement errors for both instruments and comparative measurements differ no more than 70 pptv.

The ACE-FTS PAN data set is used to obtain zonal mean distributions of seasonal averages from $\sim 5-20 \mathrm{~km}$. A strong seasonality is clearly observed for PAN concentrations in the global UTLS. Since the principal source of PAN in the UTLS is due to lofted biomass burning emissions from the pyroconvective updrafts created by large fires, the observed seasonality in enhanced PAN coincides with fire activity in different geographical regions throughout the year. 


\section{Introduction}

Peroxyacetyl nitrate $\left(\mathrm{CH}_{3} \mathrm{CO} \cdot \mathrm{O}_{2} \mathrm{NO}_{2}\right.$, abbreviated as PAN) is a trace molecular species found in the earth's atmosphere which serves as a reservoir of $\mathrm{NO}_{\mathrm{x}}\left(=\mathrm{NO}+\mathrm{NO}_{2}\right)$ and, in some regions, is the dominant form of odd nitrogen, $\mathrm{NO}_{\mathrm{y}}$ (where $\mathrm{NO}_{\mathrm{y}}=\mathrm{NO}+\mathrm{NO}_{2}+$ reservoir compounds). It plays an integral role in the oxidizing potential of the atmosphere (Moore et al., 2010).

PAN is formed through the oxidation of hydrocarbons released into the atmosphere from both anthropogenic and biogenic pollution sources. PAN is a powerful lachrymator formed in photochemical air pollution (Wayne, 2000), and the primary source of biogenic PAN is the combustion of biomass (Coheur et al., 2007; Yokelson et al., 2009; Alvarado et al., 2010; Akagi et al., 2012). The formation of PAN, and other peroxyacyl nitrates, requires the initial generation of peroxyacyl radicals, which are formed by the reaction of hydrocarbons with the hydroxyl radical $(\mathrm{OH})$ and subsequently with $\mathrm{O}_{2}$ to form $\mathrm{CH}_{3} \mathrm{CO} \cdot \mathrm{O}_{2}$ as an intermediate species. During these oxidation reactions, nitrogen monoxide (NO) is converted into nitrogen dioxide $\left(\mathrm{NO}_{2}\right)$. The reversible reaction of the peroxyacetyl radical with $\mathrm{NO}_{2}$ produces PAN:

$$
\mathrm{CH}_{3} \mathrm{CO} \cdot \mathrm{O}_{2}+\mathrm{NO}_{2} \rightleftharpoons \mathrm{CH}_{3} \mathrm{CO} \cdot \mathrm{O}_{2} \cdot \mathrm{NO}_{2}
$$

PAN is in thermal equilibrium with its precursors and the equilibrium shifts to the right in Eq. (1) with lower temperatures. It should also be noted that enhancements of tropospheric PAN have been attributed to lightning activity, where $\mathrm{NO}_{\mathrm{x}}$ produced from lightning can also react with organic precursors to form PAN (Tie et al., 2001).

Tropospheric background volume mixing ratios (VMRs) of PAN in clean air are quite variable and range typically from 10-400 pptv (Wayne, 2000). This is due to thermolysis being the primary loss mechanism for PAN in the lower troposphere. The thermal decomposition rate of PAN is highly temperature dependent, resulting in lifetimes between one hour at $298 \mathrm{~K}$ and about five months at $250 \mathrm{~K}$ (Singh, 1987). However, due to photolysis, its mean lifetime is limited to approximately 3 months. Photolysis can occur by several pathways:

$$
\begin{aligned}
\mathrm{CH}_{3} \mathrm{CO} \cdot \mathrm{O}_{2} \mathrm{NO}_{2} & \rightarrow \mathrm{CH}_{3} \mathrm{CO} \cdot \mathrm{O}+\mathrm{NO}_{3} \\
& \rightarrow \mathrm{CH}_{3} \mathrm{CO} \cdot \mathrm{O}_{2}+\mathrm{NO}_{2} \\
& \rightarrow \mathrm{CH}_{3} \mathrm{CO}+\mathrm{O}_{2}+\mathrm{NO}_{2} .
\end{aligned}
$$

The wavelength thresholds for these reactions at $298 \mathrm{~K}$ are 1025, 990 and $445 \mathrm{~nm}$, respectively (Finlayson-Pitts and Pitts, 2000).

Because of the nature of its temperature sensitivity, the lifetime of PAN is dependent on the time of day, geographical location, season and altitude. PAN can only be transported over a few hundred kilometres in the lower troposphere, but over distances of more than $10000 \mathrm{~km}$ in the cold upper troposphere (Glatthor et al., 2007). At colder temperatures, UV photolysis becomes the dominant loss mechanism. The extended lifetime of PAN in the upper troposphere permits for the transport of $\mathrm{NO}_{2}$ over great distances, which can be released in regions where active nitrogen chemistry can influence the production of surface ozone (Olszyna et al., 1994). When these polluted air masses warm up, PAN is destroyed and $\mathrm{NO}_{2}$ is released, which is then photolysed at wavelengths of less than $420 \mathrm{~nm}$. This leads to the formation of nitric oxide (NO) and atomic oxygen.

$\mathrm{NO}_{2}+h v(\lambda<420 \mathrm{~nm}) \rightleftharpoons \mathrm{NO}+\mathrm{O}$

The atomic oxygen can then react with $\mathrm{O}_{2}$ to form $\mathrm{O}_{3}$.

$\mathrm{O}+\mathrm{O}_{2}+\mathrm{M} \rightleftharpoons \mathrm{O}_{3}+\mathrm{M}$

$\mathrm{NO}_{\mathrm{x}}$ is a catalyst for the formation of tropospheric $\mathrm{O}_{3}$. NO is converted to $\mathrm{NO}_{2}$ in the initial hydrocarbon oxidation to produce PAN, and then $\mathrm{NO}_{2}$ photodissociates back to NO. It should also be noted that PAN has a minor effect on the oxidizing power of the atmosphere through its reaction with the $\mathrm{OH}$ radical, but the reaction of $\mathrm{OH}$ with PAN and its homologs is quite slow $-k<3 \times 10^{-14} \mathrm{~cm}^{3}$ molecule ${ }^{-1} \mathrm{~s}^{-1}$ at $298 \mathrm{~K}$ and can neither compete with the rate of thermal decomposition in the lower troposphere nor with photolysis at any given altitude (Talukdar et al., 1995).

PAN can be injected into the upper troposphere and lower stratosphere (UTLS) by pyroconvective updrafts generated from forest fires. It can be either formed in the lower troposphere and transported upwards or the precursors can be transported separately and then form PAN in the UTLS. Due to the extended lifetime of PAN at these higher altitudes, satellite remote detection and measurement is facilitated. PAN is potentially an important species for differentiating, characterizing and determining the photochemical age of biomass burning emissions from distinct ecosystems, which has been demonstrated using space-borne instruments (Tereszchuk et al., 2011).

The Atmospheric Chemistry Experiment Fourier Transform Spectrometer (ACE-FTS), on board the Canadian Space Agency (CSA) satellite SCISAT-1, is a high-resolution $\left(0.02 \mathrm{~cm}^{-1}\right)$ Fourier transform spectrometer used for the remote sensing of the limb of the earth's atmosphere (Bernath et al., 2005). Through the use of the solar occultation technique, ACE-FTS has wide spectral coverage in the infrared, covering a continuous region from $750-4400 \mathrm{~cm}^{-1}$, with resulting spectra having a high signal-to-noise ratio. In the absence of clouds, ACE-FTS can optimally make atmospheric limb measurements from $150 \mathrm{~km}$ down to $5 \mathrm{~km}$. Up to $30 \mathrm{oc}-$ cultations (sunrise and sunset events) are recorded on a daily basis and near-global coverage is provided over the course of a year due to the $650 \mathrm{~km}$ altitude, $74^{\circ}$ inclination, circular orbit of SCISAT-1 (Bernath et al., 2005).

The new ACE-FTS version 3.0 data set (http://www.ace. uwaterloo.ca) currently offers atmospheric profiles for over 40 molecular species (as well as their isotopologues), over 
a dozen of which are known tracers of biomass burning. Several previous studies have already been successfully conducted using ACE-FTS measurements to analyse biomass burning emissions (Rinsland et al., 2005, 2007; Dufour et al., 2006; Coheur et al., 2007; Tereszchuk et al., 2011). Retrievals of concentration profiles from satellite data require accurate laboratory spectroscopic measurements in the form of either line parameters or absorption cross sections. The necessary laboratory measurements of PAN have been provided by Allen et al. (2005b).

This work is part of an in-depth investigation into the aging and chemical evolution of biomass burning emissions in the UTLS by ACE-FTS to further our understanding of the impact of pyrogenic emissions on atmospheric chemistry, and is part of the BORTAS (quantifying the impact of BOReal forest fires on Tropospheric oxidants over the Atlantic using Aircraft and Satellites) project (http://www. geos.ed.ac.uk/research/eochem/bortas/). The BORTAS campaign (Palmer et al., 2012) was conducted on 12 July to 3 August 2011 during the boreal forest fire season in Canada. The simultaneous aerial, ground and satellite measurement campaign sought to record instances of boreal biomass burning to measure the tropospheric VMRs of short- and longlived trace molecular species from biomass burning emissions. The goal was to investigate the connection between the composition and the distribution of these pyrogenic outflows and their resulting perturbation to atmospheric chemistry, with particular focus on oxidant species to determine the overall impact on the oxidizing capacity of the free troposphere. Included in this study is the addition of new pyrogenic volatile organic compound and oxygenated volatile organic compound species, including PAN, to be retrieved by ACE-FTS in order to aid in characterization and elucidation of plume chemistry within the UTLS.

In this work, we report observations of PAN made by ACE-FTS in the detection of boreal biomass burning emissions and compare the retrievals to VMR profiles from coincident measurements made by the Michelson Interferometer for Passive Atmospheric Sounding (MIPAS) instrument on board the European Space Agency (ESA) Environmental Satellite (ENVISAT) (European Space Agency, 2000; Fischer and Oelhaf, 1996; Moore et al., 2010). PAN has already been successfully detected in spectra recorded by the balloon and satellite versions of MIPAS (MIPAS-B and MIPAS-E) and data obtained from MIPAS-E has been used to provide seasonal global PAN concentrations throughout the UTLS (Moore et al., 2010).

The MIPAS instrument on board ENVISAT was successfully launched in March 2002 as part of an ambitious and innovative payload. ENVISAT operated successfully for 10 years until April 2012, when contact was lost. The satellite was in a polar orbit at an altitude of $800 \mathrm{~km}$, with an orbital period of about 100 minutes and a reference orbit repeat cycle of 35 days. MIPAS (Fischer and Oelhaf, 1996; Fischer et al., 2008) is a Fourier transform spectrometer that provides continual limb emission measurements in the mid-infrared over the range $685-2410 \mathrm{~cm}^{-1}(14.6-4.15 \mu \mathrm{m})$. Due to problems with the instrument slide mirrors during operation, the instrument operated in two modes; during the first two years at an unapodized resolution of $0.035 \mathrm{~cm}^{-1}$ (hereafter referred to as full-resolution mode), reducing to $0.085 \mathrm{~cm}^{-1}$ (optimized-resolution mode) over the remainder of its operation. This paper concentrates on measurements from the optimized resolution mode during 2011. The instrument's field of view is approximately $3 \mathrm{~km}$ (vertical) $\times 30 \mathrm{~km}$ (horizontal) and one complete limb sequence of measurements in the optimized-resolution nominal mode consisted of 27 spectra with tangent altitudes at $70-46 \mathrm{~km}$ in $4 \mathrm{~km}$ steps, $43-31 \mathrm{~km}$ in $3 \mathrm{~km}$ steps, $29-21 \mathrm{~km}$ in $2 \mathrm{~km}$ steps and $19.5-6 \mathrm{~km}$ in $1.5 \mathrm{~km}$ steps. The lowest tangent altitude varied as a function of latitude to reduce the occurrence of cloud-contaminated spectra.

MIPAS currently offers data products for many coincident molecular species measured by ACE-FTS, and because it is also a limb-viewing instrument, MIPAS is an ideal candidate for comparison in the validation of ACE-FTS operational data. Numerous MIPAS/ACE-FTS validation studies have previously been conducted (Cortesi et al., 2007; Höpfner et al., 2007; Wetzel et al., 2007). Due to the loss of MIPAS, and ACE-FTS now recording data well beyond its expected instrument lifetime, there is a strong need to develop new infrared, limb-sounding instruments to study atmospheric composition. A potential candidate is the PREMIER project (http://www.esa.int/esaEO/ SEMUMJ8X73H_index_0.html). Proposed to ESA as part of the Earth Explorer 7 call, PREMIER is one of three candidates currently remaining in the competition. The PREMIER mission seeks to continue monitoring the UTLS by using a combination of infrared and microwave limb-imaging instruments, with a particular focus on studying the coupling between atmospheric dynamics and chemical processes.

\section{ACE-FTS PAN retrieval}

\subsection{Retrieval method}

The infrared absorption spectrum of PAN is characterized by a number of broad, structureless vibrational bands, which were reported in a series of measurements made by Allen et al. $(2005 \mathrm{a}, \mathrm{b})$ at 250,273 and $295 \mathrm{~K}$. The strongest of the bands is centred at $\sim 1740 \mathrm{~cm}^{-1}$ and contains numerous interfering water vapour lines such that it cannot be used for remote sensing. PAN can be most easily retrieved using the band at $1163 \mathrm{~cm}^{-1}$ (CO stretching), although the weaker band at $794 \mathrm{~cm}^{-1}\left(\mathrm{NO}_{2}\right.$ bending $)$ is also clearly observed.

The absorption cross sections produced by Allen et al. (2005a) have been slightly modified for this study. The baselines have been corrected to agree better with each other and the integrated band intensities were scaled to the room temperature value. It had been noticed that the integrated band 
Table 1. Spectral windows used for the detection and profile retrievals of PAN in this work compared to the windows previously used in the work conducted by Coheur et al. (2007). Included are the principal interfering species associated with the selected microwindows.

\begin{tabular}{ccc}
\hline & $\begin{array}{c}\text { Microwindows } \\
\left(\mathrm{cm}^{-1}\right)\end{array}$ & Interfering Species \\
\hline Coheur & $776.00-790.40$ & $\begin{array}{c}\text { CFC-12, HCFC-22, } \mathrm{CCl}_{4} \\
\mathrm{HNO}_{3}, \mathrm{HNO}_{4}, \mathrm{H}_{2} \mathrm{O},\end{array}$ \\
& $1140.15-1180.45$ & $\mathrm{CO}_{2}, \mathrm{O}_{3}, \mathrm{~N}_{2} \mathrm{O}, \mathrm{CH}_{4}$ \\
& & \\
& $1157.00-1161.00$ & $\mathrm{CFC}-12, \mathrm{CFC}-113, \mathrm{CFC}-114$ \\
& $1161.20-1163.30$ & CFC-115, HFC-152a \\
This work & $1167.40-1168.60$ & HFC-125, HFC-134a \\
& $1169.00-1170.80$ & HCFC-141b, HCFC-22 \\
& $1171.00-1173.00$ & HFC-23, $\mathrm{H}_{2} \mathrm{O}, \mathrm{O}_{3}, \mathrm{~N}_{2} \mathrm{O}, \mathrm{CH}_{4}$ \\
& $1176.00-1178.50$ & \\
\hline
\end{tabular}

intensity for the original measurements increased with decreasing temperature. In particular, the value associated with the cross section at $250 \mathrm{~K}$ was approximately $8 \%$ higher than at $295 \mathrm{~K}$. Generally, integrated intensities over a band system, particularly those comprising primarily fundamentals, are independent of temperature. Such a large change in band intensity over a small $45 \mathrm{~K}$ temperature range is rather unlikely, and certainly the presence of any significant overtone, combination or hot bands would, if anything, lead to a small decrease with decreasing temperature (Breeze et al., 1965). This normalization assumption is anticipated to provide the most accurate basis for a PAN retrieval. The re-normalized cross sections appear as an update in the HITRAN database (Rothman et al., 2009) and are available for download (http: //www.cfa.harvard.edu/hitran/).

PAN has been previously observed in ACE-FTS measurements of a young biomass burning plume by Coheur et al. (2007), but attempts to develop an official PAN data product presented numerous difficulties, particularly in obtaining accurate background VMRs. This was primarily due to the inability to identify a significant interfering species that was present in the calculated residual spectra. The presence of the interferer thus permitted only the retrievals of measurements containing enhanced concentrations of PAN. The interfering species has since been identified as trifluoromethane $\left(\mathrm{CHF}_{3}\right.$; HFC-23) (Harrison et al., 2012).

Version 3.0 of the ACE-FTS forward model and retrieval software, similar to the previous version 2.2 (Boone et al., 2005), was used for the PAN VMR retrievals. VMR profiles of trace gases (along with temperature and pressure) are derived from the recorded transmittance spectra via a non-linear least-squares global fit to the selected spectral region(s) for all measurements within the altitude range of interest. Table 1 provides a comparison of the microwindows used for the retrievals made by Coheur et al. (2007) and those that are utilized in this work. Also presented are the princi-

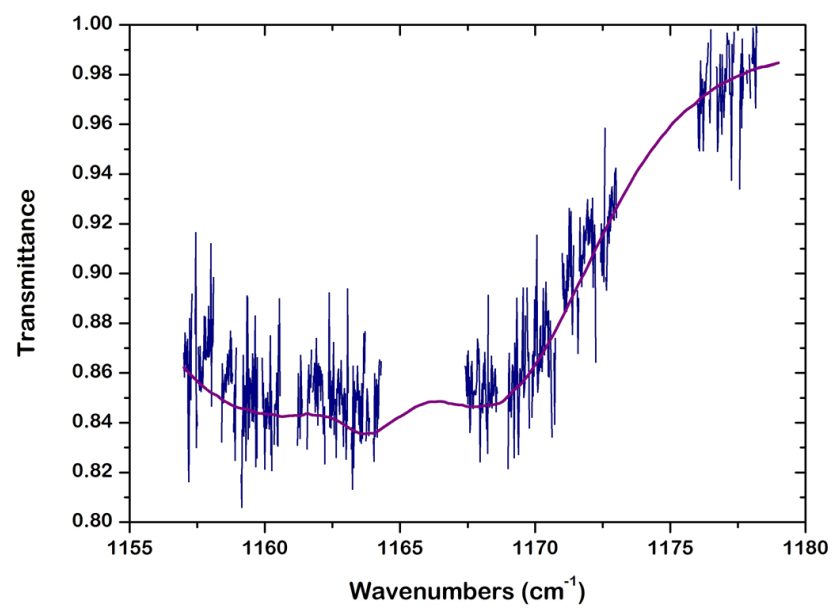

Fig. 1. PAN contribution to the measured ACE-FTS spectrum recorded at a tangent height of $7.2 \mathrm{~km}$ in occultation ss42910, determined from the ratio of the measured ACE-FTS spectrum to the calculated spectrum (for all absorbers except PAN); transmittances below 0.2 were filtered out in order to suppress the large contributions from saturated lines. Overlaid, in purple, is the calculated contribution of PAN absorption for the measurement (about $15 \%$ ).

pal interfering species found in the respective wavenumber ranges. All of the microwindows in this work share common baseline parameters (baseline scale and baseline slope) in the retrieval process. In the retrieval, minor contributions to the spectrum are explicitly calculated for HCFC-22 (using its retrieved profile), plus several other molecules using assumed VMR profiles: CFC-114, CFC-115, HFC-152a and HFC125. The molecules retrieved simultaneously with $\mathrm{PAN}$ are the following: HCFC-141b, CFC-113, HFC-134a, CFC-12, $\mathrm{CHF}_{3}, \mathrm{H}_{2} \mathrm{O}$ with isotopologues, $\mathrm{H}^{16} \mathrm{OH}, \mathrm{H}^{17} \mathrm{OH}$ and $\mathrm{HDO}$, $\mathrm{O}_{3}$ and the $\mathrm{OO}^{18} \mathrm{O}$ isotopologue, $\mathrm{N}_{2} \mathrm{O}$ with isotopologues $\mathrm{N}^{15} \mathrm{NO},{ }^{15} \mathrm{NNO}, \mathrm{NN}^{18} \mathrm{O}$ and $\mathrm{NN}^{17} \mathrm{O}$, and $\mathrm{CH}_{4}$ with isotopologues ${ }^{13} \mathrm{CH}_{4}$ and $\mathrm{CH}_{3} \mathrm{D}$.

ACE-FTS data sets are available on two grids. The first is the original, non-uniform tangent altitude grid. These correspond to the actual spectral measurements. The physical quantities (pressure, temperature and VMR) are also retrieved on a fixed $1 \mathrm{~km}$ uniform altitude grid (Boone et al., 2005). Figure 1 gives the PAN contribution to the measured ACE-FTS spectrum recorded on the tangential grid at a tangent height of $7.2 \mathrm{~km}$ in sunset occultation ss42910, which contains a measurement of a nascent $(<24 \mathrm{~h}$ old $)$ boreal biomass burning plume, recorded during the BORTAS flight campaign on 2 August 2011, over Lake Huron/Georgian Bay $\left(45.15^{\circ} \mathrm{N}, 81.99^{\circ} \mathrm{W}\right)$ from fires originating in western Ontario. The contribution was determined from the ratio of the measured ACE-FTS spectrum to the calculated spectrum (for all absorbers except PAN). There are sections of spectrum within each of the selected microwindows that have been removed. These sections correspond to regions with a transmittance value below 0.2 , and have been filtered out 

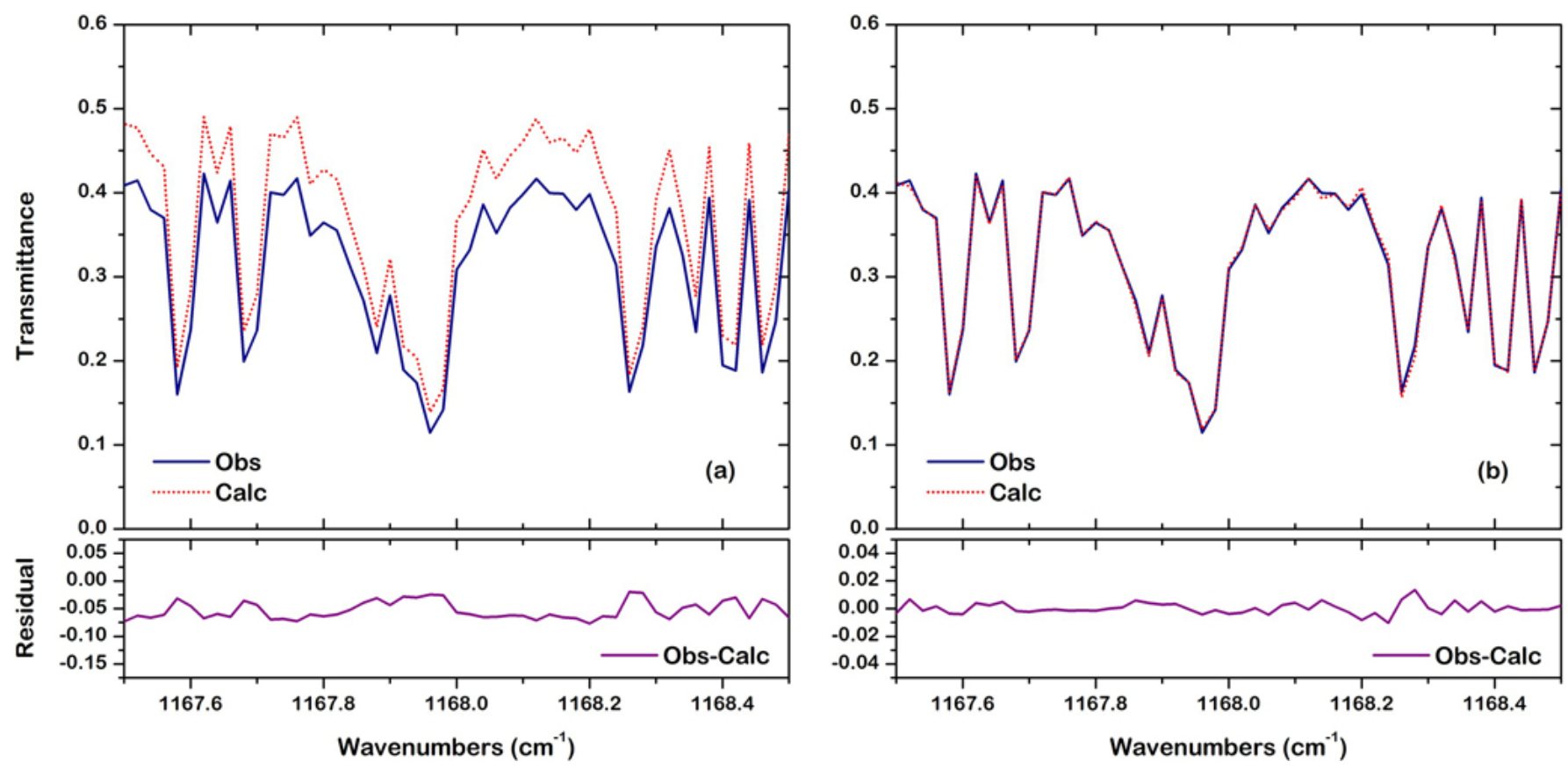

Fig. 2. Observed ACE-FTS spectrum from ss42910 (at a tangent height of $7.2 \mathrm{~km}$ ) compared to the outputs from the retrieval model for the 1167.4-1168.6 cm $\mathrm{cm}^{-1}$ microwindow, where (a) is the calculated spectrum which includes all interfering species without the inclusion of PAN and (b) the calculated spectrum with PAN included. Below each output is the associate residual calculation.

in order to suppress the large contributions from saturated lines (mainly from $\mathrm{N}_{2} \mathrm{O}$ ). Overlaid on this plot is the calculated contribution of PAN absorption for this measurement, which was obtained from the PAN VMR profile on the interpolated $1 \mathrm{~km}$ altitude grid. The contribution of PAN obtained from the broad fitting of the spectral region containing the $\mathrm{CO}$ stretching mode, centred at $1163 \mathrm{~cm}^{-1}$, is approximately $15 \%$. Figure 2 shows the observed ACE-FTS spectrum from ss42910 (at a tangent height of $7.2 \mathrm{~km}$ ) compared to the calculated outputs for the $1167.4-1168.6 \mathrm{~cm}^{-1}$ microwindow, where (a) is the calculated spectrum which includes all interfering species without the inclusion of PAN and (b) the calculated spectrum with PAN included. Below each output are the associate residual calculations. It is quite apparent that there is a negative shift in the residual spectrum when PAN is not included in the modelled output, but once the PAN VMR profile is included in the calculated spectrum, the residual values are minimized to near zero, indicating that all interfering species within the microwindow have been accounted for and thus make PAN readily retrievable from within this spectral region. From the retrieval model, the detection limit for ACE-FTS PAN is estimated to be $\sim 5 \mathrm{pptv}$ for a single occultation, which falls below the range of $10-400 \mathrm{pptv}$ for background values measured in clean marine air reported by Wayne (2000).

\subsection{Spectroscopic sources of error in the ACE-FTS retrievals}

For a single ACE-FTS profile, the 1- $\sigma$ statistical fitting errors are $\sim 20-30 \%$. Such errors are random in nature and are largely determined by the measured signal-to-noise ratios of the ACE-FTS spectra, i.e. measurement noise. Statistical errors can be reduced by averaging VMR profiles together; such averaged profiles are typically dominated by systematic errors.

One important source of systematic error arises from the PAN spectroscopic data used in the retrievals. Only three absorption cross sections recorded above $250 \mathrm{~K}$ are available; the fact that they were not recorded with additional air should have negligible contribution to the error because the band used in the retrieval is broad and likely exhibits minimal pressure broadening. At temperatures below $250 \mathrm{~K}$, this band is expected to become slightly narrower and sharper. Although the peak band absorption will increase, which one would expect to produce slightly smaller VMRs than we report, the effect on the retrieval should be partly offset by the narrowing of the band, which causes the retrieval software to lower the PAN VMR in order to obtain a "best" fit over the entire microwindow region. It is difficult to quantify the error caused by spectroscopic limitations without knowing the exact temperature dependence below $250 \mathrm{~K}$. Allen et al. $(2005 \mathrm{a}$,b) estimate the uncertainty of the cross sections as $\sim 5 \%$; however, this does not include the extrapolation error below $250 \mathrm{~K}$. We 
Table 2. Sources of systematic uncertainty in the ACE-FTS PAN retrieval.

\begin{tabular}{llc}
\hline Source & Symbol & Fractional Value \\
\hline PAN Spectroscopy & $\mu_{\text {spec }}$ & 0.08 \\
Spectral Interferers & $\mu_{\text {int }}$ & 0.01 \\
Temperature & $\mu_{T}$ & 0.10 \\
Altitude & $\mu_{z}$ & 0.10 \\
ILS & $\mu_{\text {ILS }}$ & 0.02 \\
\hline
\end{tabular}

estimate that the ACE-FTS retrieval error arising from PAN spectroscopy is $\sim 8 \%$.

Further spectroscopic errors can potentially arise from the interfering species that absorb in the PAN microwindow region. Since the baselines of the ACE-FTS transmittance spectra and the VMRs of most interferers $\left(\mathrm{H}_{2} \mathrm{O}, \mathrm{O}_{3}, \mathrm{~N}_{2} \mathrm{O}\right.$, $\mathrm{CH}_{4}$, HFC-23, HCFC-141b, CFC-113, CFC-12 and HFC134a) are fitted simultaneously with the PAN VMR, it is not a trivial exercise to determine whether they contribute to the overall systematic error of the PAN retrieval. We take the view that the lack of systematic features in the spectral residuals indicates that these contributions are negligible. However, contributions from HCFC-22, CFC-114, CFC-115, HFC-152a and HFC-125, for which the VMRs are simply fixed to either assumed or retrieved values (see Sect. 2.1), can contribute to the systematic error. Since these molecules are very weakly absorbing compared to PAN, we estimate an error of at most $\sim 1 \%$.

In addition to spectroscopic errors, uncertainties in temperature, pressure, tangent altitude (i.e. pointing) and instrumental line shape (ILS) all contribute to systematic errors in the retrieved PAN profiles. To estimate the overall systematic error, the retrieval was performed by perturbing each of these quantities $\left(b_{j}\right)$ by its assumed uncertainty $\left(\Delta b_{j}\right)$, while keeping the others unchanged. The fractional retrieval error, $\mu_{j}$, is defined as

$\mu_{j}=\left|\frac{x\left(b_{j}+\Delta b_{j}\right)-x\left(b_{j}\right)}{x\left(b_{j}\right)}\right|$,

where $x$ is the retrieved VMR.

Note that for the ACE-FTS retrievals, pressure, temperature and tangent height are not strictly independent quantities; tangent heights are determined from hydrostatic equilibrium, and so these quantities are strongly correlated. For the purposes of this work, only two of these quantities are altered: temperature is adjusted by $2 \mathrm{~K}$ (Sica et al., 2008) and tangent height by $150 \mathrm{~m}$ (Dufour et al., 2006). Additionally, ILS uncertainty is induced by adjusting the field of view by $5 \%$ (Dufour et al., 2006). A small subset of occultations was selected for this analysis. The fractional value estimates of the systematic uncertainties, and their symbols, are given in Table 2. Assuming these quantities are uncorrelated, the overall systematic error in the PAN retrieval can be
Table 3. Random Error Analysis for MIPAS PAN Retrieval.

\begin{tabular}{|c|c|c|c|c|}
\hline \multicolumn{5}{|c|}{ Random Error (\%) - Microwindow 775-787 cm ${ }^{-1}$} \\
\hline Alt. (km) & $\begin{array}{c}\text { Tropical } \\
\left(20^{\circ} \mathrm{S}-20^{\circ} \mathrm{N}\right)\end{array}$ & $\begin{array}{l}\text { Mid-Latitudes } \\
\quad\left(20-65^{\circ}\right)\end{array}$ & $\begin{array}{c}\text { Polar } \\
\text { Summer } \\
\left(65-90^{\circ}\right)\end{array}$ & $\begin{array}{c}\text { Polar } \\
\text { Winter } \\
\left(65-90^{\circ}\right)\end{array}$ \\
\hline 6 & N/A & 7.5 & 8.1 & 3.7 \\
\hline 9 & 5.8 & 5.0 & 5.8 & 5.7 \\
\hline 12 & 10.0 & 11.4 & 11.9 & 16.0 \\
\hline 15 & 46.6 & 44.7 & 41.5 & 65.1 \\
\hline 18 & 148.9 & 146.0 & 139.5 & 145.2 \\
\hline
\end{tabular}

calculated as

$\mu_{\text {systematic }}^{2}=\mu_{\text {spec }}^{2}+\mu_{\text {int }}^{2}+\mu_{T}^{2}+\mu_{z}^{2}+\mu_{\text {ILS }}^{2}$.

The total systematic error contribution to the ACE-FTS PAN retrieval is estimated to be $\sim 16 \%$.

\section{MIPAS retrieval method}

Retrievals of PAN VMRs have been achieved using the MIPAS Orbital Retrieval using Sequential Estimation (MORSE) developed by the University of Oxford (http:// www.atm.ox.ac.uk/MORSE). The scheme was used in a previous study by Moore et al. (2010) to successfully retrieve PAN VMRs in the UTLS. The scheme uses a sequential estimation approach to determine the most probable solution based on knowledge of the a priori information and the measurements. Cloudy spectra are screened using a colour index (CI) approach (Spang et al., 2012) with a threshold of 3 applied, which is adequate to remove all optically thick cloud, along with less optically thick clouds such as cirrus or cirrostratus.

Interfering species are retrieved sequentially and the microwindows used for the MIPAS retrievals are then optimized for each species of interest. The sequential joint retrieval with continuum are conducted in the order of pressure/temperature, water vapour, $\mathrm{O}_{3}, \mathrm{HNO}_{3}, \mathrm{ClONO}_{2}$ and $\mathrm{CCl}_{4}$. These inputs are then used in the joint PAN/continuum retrieval. The background continuum is constrained to low values typical of cloud-free scenes observed here; from tests, PAN retrievals show no correlation with continuum values. To prohibit unphysical negative values, all retrievals are performed in log space. From the work of Moore et al. (2010), the random error on a single retrieval could be as large as $50 \%$. By careful choice of extended microwindows (775$787 \mathrm{~cm}^{-1}$ and $794-800 \mathrm{~cm}^{-1}$ ), this has had the effect to both increase the information content within each measurement and to reduce the random noise to below $5 \%$ at each level on a single profile. A summary of the random errors for the MIPAS retrieval of PAN are found in Table 3. The detection limit for MIPAS PAN in the free troposphere varies with 

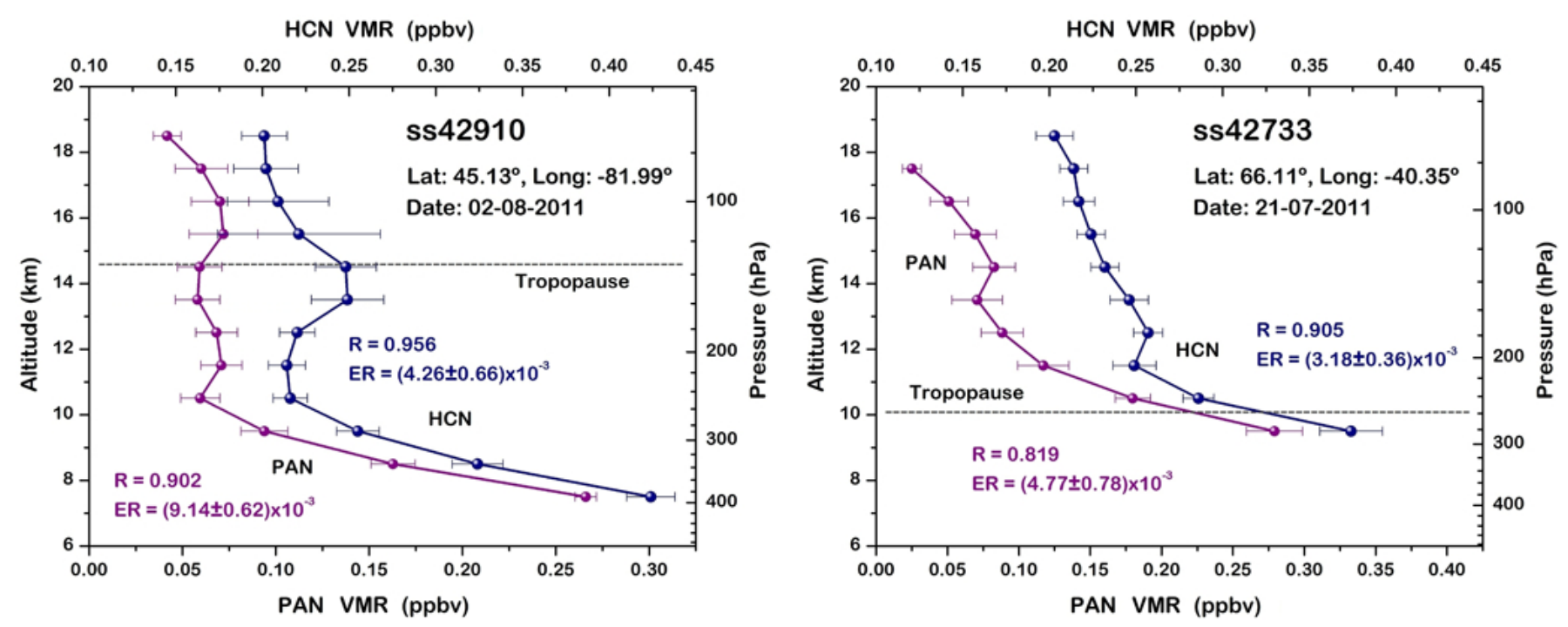

Fig. 3. ACE-FTS vertical profiles for HCN and PAN measured from boreal biomass burning plumes recorded during sunset occultations ss42910 and ss42733. Enhanced PAN and HCN are evident as ACE-FTS takes measurements of these trace species within the pyrogenic outflow. Correlation calculations were conducted for both species and the associated correlation coefficient $(R)$ and enhancement ratio (ER) with respect to $\mathrm{CO}$ are reported. The error associated with the ER calculation is the 1- $\sigma$ uncertainty in the calculation of the regression slope.

altitude. Detection limits for MIPAS PAN are approximately 20 pptv at $9 \mathrm{~km}, 30 \mathrm{pptv}$ at $12 \mathrm{~km}$ and $50 \mathrm{pptv}$ at $15 \mathrm{~km}$.

Monthly mean PAN a priori profiles are constructed using PAN fields from TOMCAT model data binned into latitude bands consistent with Remedios et al. (2007). As PAN showed little yearly variability, but strong seasonal and latitudinal variability in the model, data were taken for each season in 2003. As the sources and sinks are still poorly understood, a constant $300 \%$ a priori uncertainty was used, larger than indicated from the model, but adequately unconstrained to allow most information to be derived from the measurement rather than the a priori information.

\section{Identification of biomass burning emissions}

In the majority of studies conducted to investigate biomass burning emissions using either remote, space-borne instruments, aircraft, balloon sondes or ground stations, carbon monoxide (CO) is typically the molecular species employed to determine whether pyrogenic emissions have been sampled by comparing enhanced concentrations of $\mathrm{CO}$ relative to the background. $\mathrm{CO}$ is a well-known primary pyrogenic species with an atmospheric lifetime of approximately two months in the free troposphere, but due to it being also emitted from numerous anthropogenic sources, another longlived species that is more specific to biomass burning was chosen for plume detection. Hydrogen cyanide $(\mathrm{HCN})$ has a life time of five months and is emitted almost entirely from biomass and biofuel combustion. Typical background VMRs for $\mathrm{HCN}$ in the free troposphere have been determined to be 0.225-0.250 ppbv (Li et al., 2003; Singh et al., 2003).
In this work, ACE-FTS occultations with enhanced tropospheric VMRs of HCN $\geq 0.30 \mathrm{ppbv}$ are deemed measurements of air masses containing biomass burning emissions.

Filtering of the data was done by calculating the median PAN concentration. Retrievals which contained measurements with VMR values that were less than $10 \%$ of the median value at a given altitude were rejected as this normally indicates retrieval failure. The principal cause of retrieval failure is due to cloud contamination. ACE-FTS can effectively make measurements through thin clouds, but measurements of the free troposphere which contain thick clouds in the field of view of the instrument can cause the retrieval to fail at these altitudes, and the outcome of the retrieval is a deviation of the vertical profile to unrealistically low and even negative values for the VMR of a given molecular species. The median filtering eliminates all measurements within each occultation that contain these large deviations to assure that the measurements being used are only those where the troposphere is cloudless during the time of measurement. The remainder of the data was then filtered to remove measurements containing unrealistically large retrieval errors as they often indicate failed convergence in the retrieval. To do this, the median absolute deviation (MAD) was calculated from the associated retrieval errors; if the retrieval error at a given altitude was greater than 100 times the MAD value calculated from the data set, they too were rejected. Having filtered the data for any erroneous measurements, those occultations which contained $\mathrm{HCN}$ altitude profiles with VMRs of HCN $\geq 0.30$ ppbv were deemed measurements of biomass burning plumes. 
Figure 3 shows the vertical profiles for PAN and $\mathrm{HCN}$ obtained from the ACE-FTS data on the $1 \mathrm{~km}$ grid for sunset occultations ss 42910 and ss 42733 . Values for the altitude of the thermal tropopause were obtained from derived meteorological products (DMPs) that are produced using the ACE-FTS version 3.0 data set (Manney et al., 2007). The two occultations contain measurements of young boreal biomass burning plumes: ss 42910 ( $<24 \mathrm{~h}$ old) and ss 42733 ( $48-72 \mathrm{~h}$ old). The source and age of the plumes have been determined by using the combined, daily fire data recorded by the Moderate Resolution Imaging Spectroradiometer (MODIS) instruments on board the Aqua and Terra satellites, which was obtained from the Fire Information for Resource Management System (FIRMS) Archive Download Tool (http://earthdata.nasa. gov/data/nrt-data/firms/active-fire-data) available through NASA's Earth Observing System Data and Information System (EOSDIS). The MODIS fire counts are used concertedly with back trajectory calculations generated by the Hybrid Single Particle Lagrangian Integrated Trajectory (HYSPLIT) (Draxler and Rolph, 2003) model to locate the sources of boreal biomass burning measured by ACE-FTS. The altitude corresponding to the highest VMR of HCN for each occultation is used as the starting point of the back trajectory. Google ${ }^{\mathrm{TM}}$ Earth was used as a visualization tool to merge the data sets together in order to facilitate the determination of the sources of biomass burning plumes. Scripts were written in Keyhole Markup Language (KML) in order to import the locations of the ACE-FTS occultations and MODIS fire data into Google ${ }^{\mathrm{TM}}$ Earth along with the air-mass trajectories from HYSPLIT, which conveniently provides the option for output into the KML format. A more detailed description of the technique used in the identification, age determination and differentiation of biomass burning plumes measured by ACE-FTS can be found in the work by Tereszchuk et al. (2012). The sources of the pyrogenic outflows measured in sunset occultations ss 42910 and ss42733, in Fig. 3, are from boreal forest fires recorded during the BORTAS flight campaign. As aforementioned, ss42910 measured a nascent biomass burning plume over Lake Huron/Georgian Bay on 2 August 2011, which was emitted from fires in western Ontario. The young plume measured in ss 42733 on 21 July 2011 was recorded over the southern tip of Greenland from a large pyrogenic outflow also originating from the fires in western Ontario approximately three days earlier. In the vertical profiles for both ss 42910 and ss42733, we observe the enhancement of PAN and HCN concentrations as the instrument scans through the lofted pyrogenic outflow. In both instances, only measurements from the tops of the plumes are recorded. Measurements at lower altitudes are obstructed either due to thick clouds or there is a sufficiently high density of aerosol and particulate matter (i.e. smoke) emitted from the fires to obscure the instrument's field of view and cause the retrieval to fail at these altitudes. Correlation calculations were conducted for both species, and the classic Pearson correlation coefficient $(R)$ and the enhancement ratio (ER) with respect to $\mathrm{CO}$ obtained from the linear regression slope calculation are reported (Andreae and Merlet, 2001; Lefer et al., 1994; Hobbs et al., 2003). Both trace species correlate highly with $\mathrm{CO}$, indicating their presence as pyrogenic species within the biomass burning outflow. The $R$ values for HCN and PAN in occultation ss 42910 are 0.956 and 0.902 , respectively. The correlation constants for $\mathrm{HCN}$ and PAN in ss42733 are 0.905 and 0.819 .

\section{Comparison of ACE-FTS and MIPAS PAN retrievals}

Because ACE-FTS is on board SCISAT-1 and MIPAS on ENVISAT, it is not possible to find exact coincidences between ACE-FTS and MIPAS observations. PAN has a relatively long chemical lifetime in the cold temperatures in the UTLS (of the order several weeks, Talukdar et al., 1995) and a short time scale variability that depends mainly on transport and variation in sources. To ensure a reasonable coincidence, we decided to collocate ACE-FTS and MIPAS to within three hours and $1000 \mathrm{~km}$. The distance criteria was the most difficult obstacle to overcome due to the solar occultation measurement approach of ACE-FTS. The field of view of ACE-FTS and MIPAS is around 3 kilometres, with similar sensitivity to PAN in the UTLS. Three coincident measurements events made during BORTAS have been identified. HYSPLIT trajectories were used to determine that they are measurements of boreal biomass burning plumes originating from outflows with three different ages. Figure 4 shows the comparison of ACE-FTS, with the closest coincident MIPAS profiles, for the three identified plumes. The left panel contains a young plume, 48-72 h old (ss42733), the centre panel is of a younger plume, 24-48 h old (ss42776), and the right panel is another plume that is $48-72 \mathrm{~h}$ old (ss42893). ACE-FTS occultations ss42776 and ss42893 are near-coincident measurements and are in good agreement with respect to profile shape with a local minimum in PAN observed around the tropopause in both the ACE-FTS and MIPAS data, indicating that the plumes were confined to the upper troposphere. ACE-FTS occultation ss42733, left panel, is the closest of the coincident measurements to MIPAS made during the campaign period. Not only do the profile shapes from both instruments emulate one another but the ACE-FTS and MIPAS VMRs for PAN are well within the associated measurement errors for both instruments. The distance between the ACE-FTS occultation ss42733 and MIPAS measurement 49097 is approximately $150 \mathrm{~km}$. A quantitative comparison between the two vertical profiles, Fig. 5, shows an agreement between measurements to be within 70 pptv for the altitude range of $9.5-17.5 \mathrm{~km}$. At $8.5 \mathrm{~km}$, we observe a deviation in the VMRs which is due to the measurement of the confluence of differing air masses at these corresponding altitudes. HYSPLIT backtrajectory calculations were conducted to determine the sources of the air masses measured 

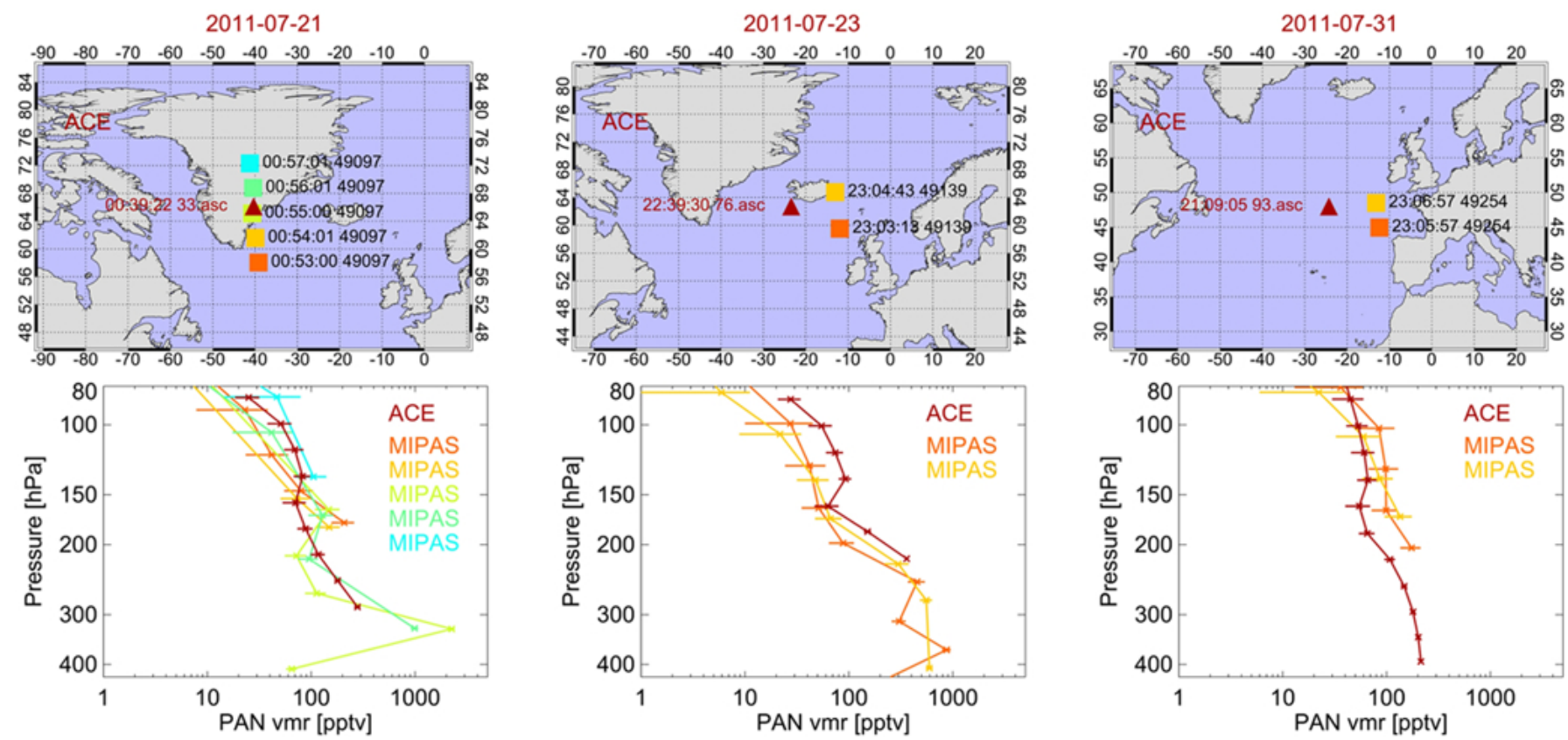

Fig. 4. Comparisons of ACE-FTS VMR profiles with coincident measurements made by MIPAS during the BORTAS campaign of boreal biomass burning outflows. The left panel contains a young plume, 48-72 h old (ss42733), the centre panel is of a younger plume, 24-48 $\mathrm{h}$ old(ss42776), and the right panel is another plume that is $48-72 \mathrm{~h}$ old (ss42893).

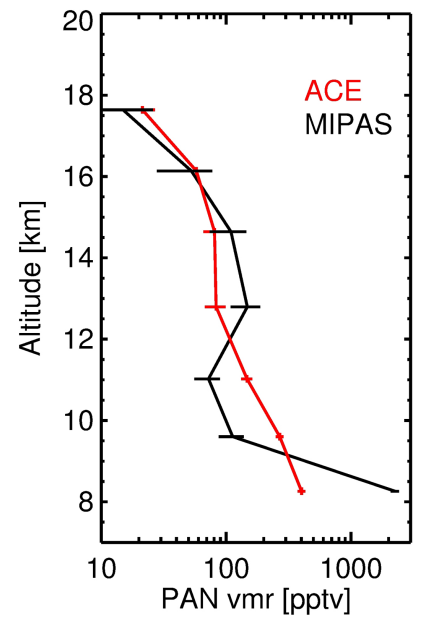

Fig. 5. Quantitative comparison between the VMR profiles recorded by ACE-FTS occultation ss42733 and MIPAS measurement 49097. The agreement between the two vertical profiles is within $70 \mathrm{pptv}$ for the altitude range between $9.5-17.5 \mathrm{~km}$. Below $9.5 \mathrm{~km}$, we observe a deviation in the VMRs which is due to the measurement of the confluence of differing air masses at these altitudes.

by MIPAS and ACE-FTS. The 5-day back trajectories for the air masses measured by both instruments between the 9.5 $17.5 \mathrm{~km}$ followed the same relative path towards the boreal fires in western Ontario, but below $9.5 \mathrm{~km}$ the back trajectories deviate. The air masses measured by MIPAS pass directly over the region of high fire intensity in western Ontario on 18 July 2011, but the air masses measured by ACE-FTS at these altitudes diverge $\sim 5^{\circ} \mathrm{N}$ of the fires, thus resulting in a measured VMR for MIPAS that is 1800 pptv greater than the ACE-FTS measurement recorded at $8.5 \mathrm{~km}$.

\section{Observed ACE-FTS PAN global distribution}

Global distributions of PAN in the UTLS, including the zonal mean cross sections of seasonal averages, are calculated to provide global distributions of this short-lived, pyrogenic species. The analysed data set consists of 20075 occultations which contained retrievable PAN profiles that were accumulated over the ACE mission from February 2004 to August 2011. Of these 20075 occultations, 9961 were accepted using the filtering method described in Sect. 4 without the threshold on HCN applied.

Figure 6 shows the plots of the zonal mean distribution of seasonal averages calculated using the 9961 filtered profiles at altitudes corresponding to the UTLS $(\sim 7-20 \mathrm{~km})$. The dashed grey line in each plot corresponds to the average thermal tropopause heights obtained from the DMPs associated with the occultations used in the analysis. From these nearglobal distributions, we observe a definite seasonality in the PAN concentrations in the UTLS. Since the main source of PAN in the UTLS is due to lofted biomass burning emissions from the pyroconvective updrafts created by large fires, the seasonality should coincide with fire activity in different geographical regions throughout the year; the PAN enhancement 

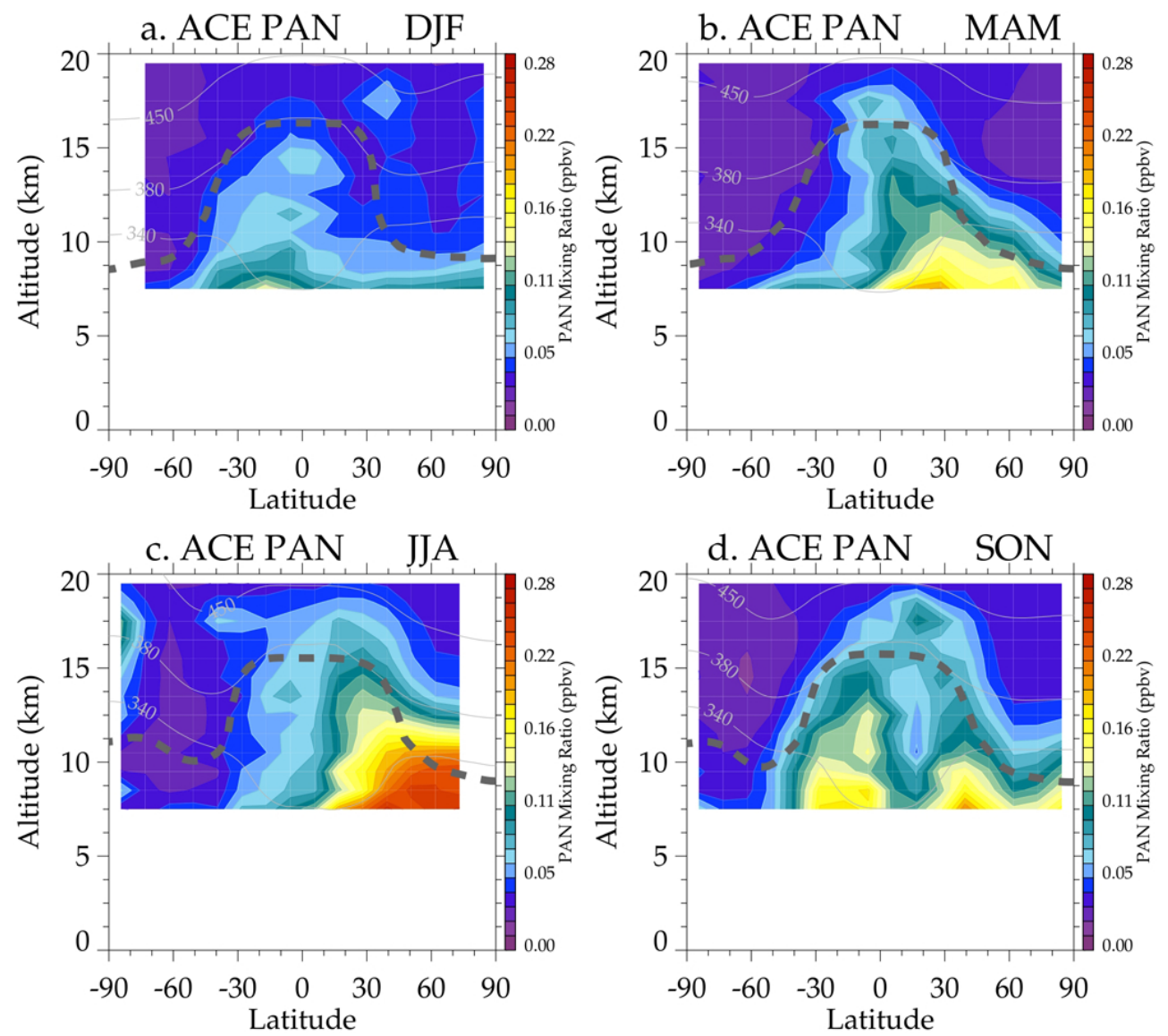

Fig. 6. Plots of the zonal mean distributions of seasonal average PAN concentrations from $\sim 5-20 \mathrm{~km}$. A definite seasonality is observed in PAN concentrations in the UTLS. The variations correspond with fire activity in different geographical regions throughout the year.

occur as expected, corroborating the seasonal fire activity observed by MODIS. During the spring (MAM) of the Northern Hemisphere, the majority of global biomass burning activity occurs in China. Elevated concentrations corresponding to the pyrogenic outflows from slash and burn activity and the burning of crop residues in the Chinese mainland is quite evident. The summer (JJA) months show elevated concentrations of PAN at latitudes further north, which corresponds to the height of boreal biomass burning activity in North America and Siberia. In the autumn (SON), PAN becomes more delocalized near equatorial latitudes; this is when fires are most prevalent in Amazonia, the South American pampas and the African Congo due to agricultural slash and burn activity that occurs in these regions. During the winter (DJF) months, fire activity peaks in the Southern Hemisphere, particularly in the Australian savanna (Tereszchuk et al., 2011), as we see elevated PAN localized to the latitudes corresponding to this particular geographical region. A similar seasonality in the global distribution of MIPAS PAN was observed by Moore et al. (2010). The zonal averages of MIPAS PAN measurements were calculated for the months of January, March, August and October of 2003. The result- ing output also demonstrates a seasonality which is coincident with biomass burning activity. In March, we once again observe the emissions corresponding to the agricultural practices in mainland China and Russia. The month of August clearly shows boreal forest fire activity in the high latitudes of the Northern Hemisphere. Elevated PAN concentrations in October are delocalized over the equator from the biomass burning emissions from fires in Amazonia and the Congo. January shows very little enhancement in global PAN concentrations. Normally, during this month, we would observe enhancements in the concentrations of pyrogenic species in the Southern Hemisphere as it coincides with the wildfire season in Australia. January 2003 was marked by immense fire activity in the Canberra region, but towards the end of the month, which may explain why the emissions from these fires are not reflected averaged PAN measurements made during this month. 


\section{Conclusions}

We report measurements of PAN in boreal biomass burning emissions recorded from infrared limb spectra of the earth's atmosphere obtained by solar occultations from the Atmospheric Chemistry Experiment Fourier Transform Spectrometer (ACE-FTS) during the BORTAS campaign. VMRs profiles for PAN were retrieved using absorption cross sections generated from high-resolution infrared laboratory spectra of PAN provided by Allen et al. (2005b). The cross sections were incorporated into the ACE-FTS forward and retrieval model and retrieved using a selection of microwindows in the $1157.00-1178.50 \mathrm{~cm}^{-1}$ region. We estimate a detection limit for ACE-FTS PAN to be approximately 5 pptv and have determined that the total systematic error contribution to the ACE-FTS PAN retrieval is $\sim 16 \%$.

The ACE-FTS retrievals are compared to coincident measurements made by the Michelson Interferometer for Passive Atmospheric Sounding (MIPAS) instrument on the European Space Agency (ESA) Environmental Satellite (ENVISAT). The MIPAS measurements demonstrated good agreement with the ACE-FTS VMR profiles for PAN, where the measured VMR values are well within the associated measurement errors for both instruments and comparative measurements differ by a maximum of 70 pptv.

The zonal mean distributions of the seasonal averages from $\sim 7-20 \mathrm{~km}$ were calculated from the ACE-FTS PAN data set. We observe a strong seasonality in the PAN concentrations in the UTLS. Since the principal source of PAN in the UTLS is due to lofted biomass burning emissions from the pyroconvective updrafts created by large fires, the observed seasonality in enhanced PAN coincides with fire activity in different geographical regions throughout the year.

Acknowledgements. The ACE mission is funded primarily by the Canadian Space Agency (CSA). The authors would like to thank the Natural Environment Research Council (NERC) of the United Kingdom for supporting K. A. Tereszchuk and J. J. Harrison through grant NE/F017391/1 (BORTAS) and for partial support through grant NE/H003673/1 (NCEO Mission Support: PREMIER). D. P. Moore would like to thank the National Centre for Earth Observation (NCEO) of the United Kingdom for funding, the European Space Agency (ESA) for provision of MIPAS data through CUTLSOM project A0-158, and Anu Dudhia for providing the MORSE algorithm. M. Park would like to thank the National Center for Atmospheric Research (NCAR). NCAR is operated by the University Corporation for Atmospheric Research (UCAR) under sponsorship of the National Science Foundation (NSF) of the United States of America.

Edited by: S. Matthiesen

\section{References}

Akagi, S. K., Craven, J. S., Taylor, J. W., McMeeking, G. R., Yokelson, R. J., Burling, I. R., Urbanski, S. P., Wold, C. E., Seinfeld, J. H., Coe, H., Alvarado, M. J., and Weise, D. R.: Evolution of trace gases and particles emitted by a chaparral fire in California, Atmos. Chem. Phys., 12, 1397-1421, doi:10.5194/acp-12-13972012, 2012.

Allen, G., Remedios, J. J., Newnham, D. A., Smith, K. M., and Monks, P. S.: Improved mid-infrared cross-sections for peroxyacetyl nitrate (PAN) vapour, Atmos. Chem. Phys., 5, 47-56, doi:10.5194/acp-5-47-2005, 2005a.

Allen, G., Remedios, J. J., and Smith, K. M.: Low temperature midinfrared cross-sections for peroxyacetyl nitrate (PAN) vapour, Atmos. Chem. Phys., 5, 3153-3158, doi:10.5194/acp-5-31532005, 2005b.

Alvarado, M. J., Logan, J. A., Mao, J., Apel, E., Riemer, D., Blake, D., Cohen, R. C., Min, K.-E., Perring, A. E., Browne, E. C., Wooldridge, P. J., Diskin, G. S., Sachse, G. W., Fuelberg, H., Sessions, W. R., Harrigan, D. L., Huey, G., Liao, J., Case-Hanks, A., Jimenez, J. L., Cubison, M. J., Vay, S. A., Weinheimer, A. J., Knapp, D. J., Montzka, D. D., Flocke, F. M., Pollack, I. B., Wennberg, P. O., Kurten, A., Crounse, J., Clair, J. M. St., Wisthaler, A., Mikoviny, T., Yantosca, R. M., Carouge, C. C., and Le Sager, P.: Nitrogen oxides and PAN in plumes from boreal fires during ARCTAS-B and their impact on ozone: an integrated analysis of aircraft and satellite observations, Atmos. Chem. Phys., 10, 9739-9760, doi:10.5194/acp-10-9739-2010, 2010.

Andreae, M. O. and Merlet, P.: Emission of trace gases and aerosols from biomass burning, Global. Biogeochem. Cy., 15, 955-966, 2001.

Bernath, P. F., McElroy, C. T., Abrams, M. C., Boone, C. D., Butler, M., Camy-Peyret, C., Carleer, M., Clerbaux, C., Coheur, P.-F., Colin, R., DeCola, P., DeMazière, M., Drummond, J. R., Dufour, D., Evans, W. F. J., Fast, H., Fussen, D., Gilbert, K., Jennings, D. E., Llewellyn, E. J., Lowe, R. P., Mahieu, E., McConnell, J. C., McHugh, M., McLeod, S. D., Michaud, R., Midwinter, C., Nassar, R., Nichitiu, F., Nowlan, C., Rinsland, C. P., Rochon, Y. J., Rowlands, N., Semeniuk, K., Simon, P., Skelton, R., Sloan, J. J., Soucy, M.-A., Strong, K., Tremblay, P., Turnbull, D., Walker, K.A., Walkty, I., Wardle, D. A., Wehrle, V., Zander, R., and Zou, J.: Atmospheric Chemistry Experiment (ACE): Mission overview, Geophys. Res. Lett., 32, L15S01, doi:10.1029/2005GL022386, 2005.

Boone, C. D., Nassar, R., Walker, K. A., Rochon, Y., McLeod, S. D., Rinsland, C. P., and Bernath, P. F.: Retrievals for the atmospheric chemistry experiment Fourier-transform spectrometer, Appl. Opt., 44, 7218-7231, 2005.

Breeze, J. C., Ferriso, C. C., Ludwig, C. B., and Malkmus, W.: Temperature Dependence of the Total Integrated Intensity of Vibrational-Rotational Band Systems, J. Chem. Phys., 42, 402406, 1965.

Coheur, P.-F., Herbin, H., Clerbaux, C., Hurtmans, D., Wespes, C., Carleer, M., Turquety, S., Rinsland, C. P., Remedios, J., Hauglustaine, D., Boone, C. D., and Bernath, P. F.: ACE-FTS observation of a young biomass burning plume: first reported measurements of $\mathrm{C}_{2} \mathrm{H}_{4}, \mathrm{C}_{3} \mathrm{H}_{6} \mathrm{O}, \mathrm{H}_{2} \mathrm{CO}$ and PAN by infrared occultation from space, Atmos. Chem. Phys., 7, 5437-5446, doi:10.5194/acp-75437-2007, 2007. 
Cortesi, U., Lambert, J. C., De Clercq, C., Bianchini, G., Blumenstock, T., Bracher, A., Castelli, E., Catoire, V., Chance, K. V., De Mazière, M., Demoulin, P., Godin-Beekmann, S., Jones, N., Jucks, K., Keim, C., Kerzenmacher, T., Kuellmann, H., Kuttippurath, J., Iarlori, M., Liu, G. Y., Liu, Y., McDermid, I. S., Meijer, Y. J., Mencaraglia, F., Mikuteit, S., Oelhaf, H., Piccolo, C., Pirre, M., Raspollini, P., Ravegnani, F., Reburn, W. J., Redaelli, G., Remedios, J. J., Sembhi, H., Smale, D., Steck, T., Taddei, A., Varotsos, C., Vigouroux, C., Waterfall, A., Wetzel, G., and Wood, S.: Geophysical validation of MIPAS-ENVISAT operational ozone data, Atmos. Chem. Phys., 7, 4807-4867, doi:10.5194/acp-7-4807-2007, 2007.

Draxler, R. R. and Rolph, G. D.: HYSPLIT (HYbrid Single-Particle Lagrangian Integrated Trajectory) Model, NOAA Air Resources Laboratory, Silver Spring, MD, available at: http://www.arl.noaa. gov/ready/hysplit4.html (last access: October 2012), 2003.

Dufour, G., Boone, C. D., Rinsland, C. P., and Bernath, P. F.: First space-borne measurements of methanol inside aged southern tropical to mid-latitude biomass burning plumes using the ACE-FTS instrument, Atmos. Chem. Phys., 6, 3463-3470, doi:10.5194/acp-6-3463-2006, 2006.

European Space Agency: Envisat, MIPAS An instrument for atmospheric chemistry and climate research, ESA Publications Division, ESTEC, P.O. Box 299, 2200 AG Noordwijk, the Netherlands, SP-1229, 2000.

Finlayson-Pitts, B. J. and Pitts, J. N.: Chemistry of the Upper and Lower Atmosphere - Theory, Experiments and Applications, Academic Press, p. 103, 2000.

Fischer, H. and Oelhaf, H.: Remote sensing of vertical profiles of atmospheric trace constituents with MIPAS limb-emission spectrometers, Appl. Opt., 35, 2787-2796, 1996.

Fischer, H., Birk, M., Blom, C., Carli, B., Carlotti, M., von Clarmann, T., Delbouille, L., Dudhia, A., Ehhalt, D., Endemann, M., Flaud, J. M., Gessner, R., Kleinert, A., Koopman, R., Langen, J., López-Puertas, M., Mosner, P., Nett, H., Oelhaf, H., Perron, G., Remedios, J., Ridolfi, M., Stiller, G., and Zander, R.: MIPAS: an instrument for atmospheric and climate research, Atmos. Chem. Phys., 8, 2151-2188, doi:10.5194/acp-8-2151-2008, 2008.

Glatthor, N., von Clarmann, T., Fischer, H., Funke, B., Grabowski, U., Höpfner, M., Kellmann, S., Kiefer, M., Linden, A., Milz, M., Steck, T., and Stiller, G. P.: Global peroxyacetyl nitrate (PAN) retrieval in the upper troposphere from limb emission spectra of the Michelson Interferometer for Passive Atmospheric Sounding (MIPAS), Atmos. Chem. Phys., 7, 2775-2787, doi:10.5194/acp7-2775-2007, 2007.

Harrison, J. J., Boone, C. D., Brown, A. T., Allen, N. D. C., Toon, G. C., and Bernath, P. F.: First remote sensing observations of trifluoromethane (HFC-23) in the upper troposphere and lower stratosphere, J. Geophys. Res., 117, D05308, doi:10.1029/2011JD016423, 2012.

Hobbs, P. V., Sinha, P., Yokelson, R. J., Christian, T. J., Blake, D. R., Gao, S., Kirchstetter, T. W., Novakov, T., and Pilewskie, P.: Evolution of gases and particles from a savanna fire in South Africa, J. Geophys. Res., 108, 8485, doi:10.1029/2002JD002352, 2003.

Höpfner, M., von Clarmann, T., Fischer, H., Funke, B., Glatthor, N., Grabowski, U., Kellmann, S., Kiefer, M., Linden, A., Milz, M., Steck, T., Stiller, G. P., Bernath, P., Blom, C. E., Blumenstock, Th., Boone, C., Chance, K., Coffey, M. T., Friedl-Vallon, F., Griffith, D., Hannigan, J. W., Hase, F., Jones, N., Jucks, K. W., Keim,
C., Kleinert, A., Kouker, W., Liu, G. Y., Mahieu, E., Mellqvist, J., Mikuteit, S., Notholt, J., Oelhaf, H., Piesch, C., Reddmann, T., Ruhnke, R., Schneider, M., Strandberg, A., Toon, G., Walker, K. A., Warneke, T., Wetzel, G., Wood, S., and Zander, R.: Validation of MIPAS ClONO2 measurements, Atmos. Chem. Phys., 7, 257-281, doi:10.5194/acp-7-257-2007, 2007.

Lefer, B. L., Talbot R. W., Harriss, R. H., Bradshaw, J. D., Sandholm, S. T., Olson, J. O., Sachse, G. W., Collins, J., Shipham, M. A., Blake, D. R., Klemm, K. I., Klemm, O., Gorzelska, K., and Barrick, J.: Enhancement of acidic gases in biomass burning impacted air masses over Canada, J. Geophys. Res., 99, 1721-1737, 1994.

Li, Q., Jacob, D. J., Yantosca, R. M., Heald, C. L., Singh, H. B., Koike, M., Zhao, Y., Sachse, G. W., and Streets, D. G.: A global three-dimensional model analysis of the atmospheric budgets of $\mathrm{HCN}$ and $\mathrm{CH}_{3} \mathrm{CN}$ : Constraints from aircraft and ground measurements, J. Geophys. Res., 108, 8827, doi:10.1029/2002JD003075, 2003.

Manney, G. L., Daffer, W. H., Zawodny, J. M., Bernath, P. F., Hoppel, K. W., Walker, K. A., Knosp, B. W., Boone, C., Remsberg, E. E., Santee, M. L., Harvey, V. L., Pawson, S., Jackson, D. R., Deaver, L., McElroy, C. T., McLinden, C. A., Drummond, J. R., Pumphrey, H. C., Lambert, A., Schwartz, M. J., Froidevaux, L., McLeod, S., Takacs, L. L., Suarez, M. J., Trepte, C. R., Cuddy, D. C., Livesey, N. J., Harwood, R. S., and Waters, J. W. : Solar occultation satellite data and derived meteorological products: sampling issues and comparisons with Aura MLS, J. Geophys. Res., 112, D24S50, doi:10.1029/2007JD008709, 2007.

Moore, D. P. and Remedios, J. J.: Seasonality of Peroxyacetyl nitrate (PAN) in the upper troposphere and lower stratosphere using the MIPAS-E instrument, Atmos. Chem. Phys., 10, 6117-6128, doi:10.5194/acp-10-6117-2010, 2010.

Olszyna, K. J., Bailey, E. M., Simonaitis, R., and Meagher, J. F.: $\mathrm{O}_{3}$ and $\mathrm{NO}_{\mathrm{y}}$ relationships at a rural site, J. Geophys. Res.-Atmos., 99, 14557-14563, 1994.

Palmer, P. I., Parrington, M., Lee, J. D., Lewis, A. C., Rickard, A. R., Bernath, P. F., Duck, T. J., Waugh, D. L., Tarasick, D. W., Andrews, S., Aruffo, E., Bailey, L. J., Barrett, E., Bauguitte, S. J.B., Curry, K. R., Di Carlo, P., Chisholm, L., Dan, L., Forster, G., Franklin, J. E., Gibson, M. D., Griffin, D., Helmig, D., Hopkins, J. R., Hopper, J. T., Jenkin, M. E., Kindred, D., Kliever, J., Le Breton, M., Matthiesen, S., Maurice, M., Moller, S., Moore, D. P., Oram, D. E., O'Shea, S. J., Christopher Owen, R., Pagniello, C. M. L. S., Pawson, S., Percival, C. J., Pierce, J. R., Punjabi, S., Purvis, R. M., Remedios, J. J., Rotermund, K. M., Sakamoto, K. M., da Silva, A. M., Strawbridge, K. B., Strong, K., Taylor, J., Trigwell, R., Tereszchuk, K. A., Walker, K. A., Weaver, D., Whaley, C., and Young, J. C.: Quantifying the impact of BOReal forest fires on Tropospheric oxidants over the Atlantic using Aircraft and Satellites (BORTAS) experiment: design, execution and science overview, Atmos. Chem. Phys. Discuss., 13, 4127-4181, doi:10.5194/acpd-13-4127-2013, 2013.

Remedios, J. J., Leigh, R. J., Waterfall, A. M., Moore, D. P., Sembhi, H., Parkes, I., Greenhough, J., Chipperfield, M.P., and Hauglustaine, D.: MIPAS reference atmospheres and comparisons to V4.61/V4.62 MIPAS level 2 geophysical data sets, Atmos. Chem. Phys. Discuss., 7, 9973-10017, doi:10.5194/acpd-79973-2007, 2007. 
Rinsland, C. P., Dufour, G., Boone, C. D., Bernath, P. F., and Chiou, L.: Atmospheric Chemistry Experiment (ACE) measurements of elevated Southern Hemisphere upper tropospheric $\mathrm{CO}, \mathrm{C}_{2} \mathrm{H}_{6}$, $\mathrm{HCN}$, and $\mathrm{C}_{2} \mathrm{H}_{2}$ mixing ratios from biomass burning emissions and long-range transport, Geophys. Res. Lett., 32, L20803, doi:10.1029/2005GL024214, 2005.

Rinsland, C. P., Dufour, G., Boone, C. D., Bernath, P. F., Chiou, L., Coheur, P.-F., Turquety, S., and Clerbaux, C.: Satellite boreal measurements over Alaska and Canada during June-July 2004: Simultaneous measurements of upper tropospheric $\mathrm{CO}$, $\mathrm{C}_{2} \mathrm{H}_{6}, \mathrm{HCN}, \mathrm{CH}_{3} \mathrm{Cl}, \mathrm{CH}_{4}, \mathrm{C}_{2} \mathrm{H}_{2}, \mathrm{CH}_{3} \mathrm{OH}, \mathrm{HCOOH}, \mathrm{OCS}$, and $\mathrm{SF}_{6}$ mixing ratios, Global Biogeochem. Cy., 21, GB3008, doi:10.1029/2006GB002795, 2007.

Rothman, L. S., Gordon, I. E., Barbe, A., Benner, D. C., Bernath, P. F., Birk, M., Boudon, V., Brown, L. R., Campargue, A., Champion, J.-P., Chance, K., Coudert, L. H., Dana, V., Devi, V. M., Fally, S., Flaud, J.-M., Gamache, R. R., Goldman, A., Jacquemart, D., Kleiner, I., Lacome, N., Lafferty, W. J., Mandin, J.Y., Massie, S. T., Mikhailenko, S. N., Miller, C. E., MoazzenAhmadi, N., Naumenko, O. V., Nikitin, A. V., Orphal, J., Perevalov, V. I., Perrin, A., Predoi-Cross, A., Rinsland, C. P., Rotger, M., Šimečková, M., Smith, M. A. H., Sung, K., Tashkun, S. A., Tennyson, J., Toth, R. A., Vandaele, A. C., and Vander Auwera, J.: The HITRAN 2008 molecular spectroscopic database, J. Quant. Spectrosc. Ra., 110, 533-572, 2009.

Sica, R. J., Izawa, M. R. M., Walker, K. A., Boone, C., Petelina, S. V., Argall, P. S., Bernath, P., Burns, G. B., Catoire, V., Collins, R. L., Daffer, W. H., De Clercq, C., Fan, Z. Y., Firanski, B. J., French, W. J. R., Gerard, P., Gerding, M., Granville, J., Innis, J. L., Keckhut, P., Kerzenmacher, T., Klekociuk, A. R., Kyrö, E., Lambert, J. C., Llewellyn, E. J., Manney, G. L., McDermid, I. S., Mizutani, K., Murayama, Y., Piccolo, C., Raspollini, P., Ridolfi, M., Robert, C., Steinbrecht, W., Strawbridge, K. B., Strong, K., Stübi, R., and Thurairajah, B.: Validation of the Atmospheric Chemistry Experiment (ACE) version 2.2 temperature using ground-based and space-borne measurements, Atmos. Chem. Phys., 8, 35-62, doi:10.5194/acp-8-35-2008, 2008.

Singh, H. B.: Reactive nitrogen in the troposphere, Environ. Sci. Technol., 21, 32-327, doi:10.1021/es00158a001, 1987.

Singh, H. B., Salas, L., Herlth, D., Kolyer, R., Czech, E., Viezee, W., Li, Q., Jacob, D. J., Blake, D., Sachse, G., Harward, C. N., Fuelberg, H., Kiley, C. M., Zhao, Y., and Kondo, Y.: In situ measurements of $\mathrm{HCN}$ and $\mathrm{CH}_{3} \mathrm{CN}$ over the Pacific Ocean: Sources, sinks, and budgets, J. Geophys. Res., 108, 8795, doi:10.1029/2002JD003006, 2003.
Spang, R., Arndt, K., Dudhia, A., Höpfner, M., Hoffmann, L., Hurley, J., Grainger, R. G., Griessbach, S., Poulsen, C., Remedios, J. J., Riese, M., Sembhi, H., Siddans, R., Waterfall, A., and Zehner, C.: Fast cloud parameter retrievals of MIPAS/Envisat, Atmos. Chem. Phys., 12, 7135-7164, doi:10.5194/acp-12-71352012, 2012.

Talukdar, R. K., Burkholder, J. B., Schmoltner, A., Roberts, J. M., Wilson, R. R., and Ravishankara, A. R.: Investigation of the loss processes for peroxyacetyl nitrate in the atmosphere: UV photolysis and reaction with $\mathrm{OH}$, J. Geophys. Res.-Atmos., 100, 14163-14173, 1995.

Tereszchuk, K. A., González Abad, G., Clerbaux, C., Hurtmans, D., Coheur, P.-F., and Bernath, P. F.: ACE-FTS measurements of trace species in the characterization of biomass burning plumes, Atmos. Chem. Phys., 11, 12169-12179, doi:10.5194/acp-1112169-2011, 2011.

Tereszchuk, K. A., González Abad, G., Clerbaux, C., Hadji-Lazaro, J., Hurtmans, D., Coheur, P.-F., and Bernath, P. F.: ACE-FTS observations of pyrogenic trace species in boreal biomass burning plumes during BORTAS, Atmos. Chem. Phys., 13, 4529-4541, doi:10.5194/acp-13-4529-2013, 2013.

Tie, X., Zhang, R., Brasseur, G., Emmons, L. and Lei, W.: Effects of lightning on reactive nitrogen and nitrogen reservoir species in the troposhere, J. Geophys. Res., 106, 3167-3178, 2001.

Wayne, R. P.: Chemistry of the atmospheres, 3rd Edn., Oxford science publications, Clarendon Press, Oxford, p. 337, 2000.

Wetzel, G., Bracher, A., Funke, B., Goutail, F., Hendrick, F., Lambert, J.-C., Mikuteit, S., Piccolo, C., Pirre, M., Bazureau, A., Belotti, C., Blumenstock, T., De Mazière, M., Fischer, H., Huret, N., Ionov, D., López-Puertas, M., Maucher, G., Oelhaf, H., Pommereau, J.-P., Ruhnke, R., Sinnhuber, M., Stiller, G., Van Roozendael, M., and Zhang, G.: Validation of MIPASENVISAT $\mathrm{NO}_{2}$ operational data, Atmos. Chem. Phys., 7, 32613284, doi:10.5194/acp-7-3261-2007, 2007.

Yokelson, R. J., Crounse, J. D., DeCarlo, P. F., Karl, T., Urbanski, S., Atlas, E., Campos, T., Shinozuka, Y., Kapustin, V., Clarke, A. D., Weinheimer, A., Knapp, D. J., Montzka, D. D., Holloway, J., Weibring, P., Flocke, F., Zheng, W., Toohey, D., Wennberg, P. O., Wiedinmyer, C., Mauldin, L., Fried, A., Richter, D., Walega, J., Jimenez, J. L., Adachi, K., Buseck, P. R., Hall, S. R., and Shetter, R.: Emissions from biomass burning in the Yucatan, Atmos. Chem. Phys., 9, 5785-5812, doi:10.5194/acp-9-5785-2009, 2009. 